\title{
Hungry for housing: waqf real estate development - a social welfare alternative
}

\author{
Siti Nadiah Mohd Ali ${ }^{1 a}$, Abdul Halim Mohd Noor ${ }^{2}$,Noraini Johari ${ }^{1}$, Nurul Sahida Fauzi ${ }^{1}$, Nor Nazihah Chuweni ${ }^{1}$ and Nor \\ Rashidah Paujah Ismail ${ }^{3}$ \\ ${ }^{1}$ Faculty of Architecture, Planning and Surveying, Universiti Teknologi MARA, Seri Iskandar Campus, Seri Iskandar, 32610, Perak, \\ Malaysia \\ ${ }^{2}$ Center for Islamic Philanthropy and Social Finance (CIPSF), 78000 Alor Gajah, Melaka Universiti Teknologi MARA, Malaysia \\ ${ }^{3}$ Faculty of Computer Science, Universiti Teknologi MARA, Tapah Campus, Tapah Road, 35400, Perak, Malaysia
}

\begin{abstract}
Islam has outlined 4 important elements to achieve fruitful life in the duniya and the akhirah. A famed hadith of Rasulullah (peace be upon him) meaning "Four things that will bring joy to a person, which is (owning) a pious woman (wife), a good house (spacious), a good neighbour, and a great vehicle" (Hadith narrated by Ibnu Hibban. It is clear from this hadith that Islam emphasised ownership of a comfortable home. The polemic remains that with skyrocketing housing prices in the market, would the low and middle income groups afford housing that is safe, comfortable and secure? Realising the importance of living in a secure and safe house, this study aims at investigating the possibility of leveraging the upward trend of waqf real estate development in empowering the Muslims' economy in the country. Towards this end, the authors have conducted a study by collating primary and secondary data obtained from the Penang State Islamic Religious Council (Majlis Agama Islam Pulau Pinang) for analysis. Thus the Penang Islamic Council is the study site. Semi structured interviews were conducted with 2 waqf officials who are in charge of coordinating waqf real estate developments in Penang. Based on the study conducted, it was found that Penang State Islamic Religious Council has succeeded in enhancing value added to waqf real estate developments through the implementation of 9 housing project developments using the ijarah concept. The Penang State Islamic Religious Council has enabled the low medium income groups to stay in comfortable and safe housing by utilising such holistic and efficient waqf product developments under shariah guidelines.
\end{abstract}

Keywords: Affordable Housing, Low and Middle Income Groups, Waqf Real Estate Development, State Islamic Religious Council, al-Ijarah

\section{Introduction}

Waqf has been literally defined as "to stop, contain, or to preserve'; in the context of land waqf is real estate that has been donated for charity by the donor towards the greater good of the community (ummah) for the sake of Allah (SWT). Once a real estate has been donated for charity (waqf) it cannot be reclaimed by the original owner to be gifted, used as inheritance or sold; in line with the waqf definition itself. The IIUM Endowment Fund related that in shari'ah, a Waqf is a voluntary, permanent, irrevocable dedication of a portion of one's wealth - in cash or kind - to Allah. A waqf real estate belongs to Allah and the corpus of the waqf always remains intact. The fruits of the waqf may be utilized for shari'ah compliant purpose.This is based on a famed hadith narrated by Ibn 'Abbas:

\footnotetext{
${ }^{\mathrm{a}}$ Corresponding author: sitin190@perak.uitm.edu.my
}

"The Messenger of Allah said: 'The one who takes back his gift is like the dog which vomits then goes back to its vomit [1]"

Thus this hadith augmented the conviction that if a waqf real estate development is revocable via the withdrawal of a waqf donation, this will undermine the social value of waqf which aspires to solve the community's social woes. The progress of waqf real estate developments in developed Islamic countries such as Turkey is a case in point. Turkey's waqf system is so progressive that it has created 4,400 mosques, 500 university hostels, 150 hotels, 5,348 shophouses and 2,254 housing projects. It is heartening that the waqf system has been Turkey's 'bread and butter' since the Uthmaniyyah Caliphate era [2].

A renowned Turkish writer B. Yediyyildiz wrote in his book "Place of the Waqf in Turkish Cultural System" waxing on the significance of waqf that: 
"... a person would have been born into a waqf house, slept in a waqf cradle, eaten and drunk from waqf property, read waqf books, been taught in a waqf school, received his salary from a waqf administration, and when he died, placed in a waqf coffin and buried in a waqf cemetery.[3]

Thus waqf plays an important role in ensuring a stable and non-capitalistic social mobility system preventing the rich getting richer and the poor getting even poorer due to the inability of waqf to fulfil its expected role.

Waqf is given due honour in Islam as an enduring reward even after the donor has died. A Muslim believes that life is not only in this world but the afterlife (akhirah) is the eternal life where the waqf we created in the worldly life will convert into a most valuable reward. Due to the significance of waqf benevolence to the ummah, Allah SWT said in Surat Al-Baqarah, verse 261 translated as:

The example of those who spend their wealth in the way of Allah is like a seed [of grain] which grows seven spikes; in each spike is a hundred grains. And Allah multiplies [His reward] for whom He wills. And Allah is all-Encompassing and Knowing. [4]

Waqf enriches a Muslim's soul and personality contributing towards his physical and spiritual happiness. Waqf bridges the poor and the rich in a symbiotic relationship. Not many realise that the waqf system possesses potential sustainability in empowering the Muslim economy in this country.

The establishment of the Department of Awqaf, Zakat and Hajj (JAWHAR) on $27^{\text {th }}$ March 2004 signalled that waqf real estate development has cut a niche in Malaysia. The formation of JAWHAR led to the creation of the Waqf Foundation which was officially incorporated on $23^{\text {rd }}$ July 2008 under the Trustees Incorporation Act 1952 (Revised 1981) JAWHAR.

The government accorded waqf serious attention as the Chairman of the Waqf Foundation of Malaysia Board of Trustees is the Honourable Minister with Religious Portfolio at the Prime Minister's Department, while the Vice Chairman is the JAWHAR Director General. Other members of the Board of Trustees comprise representatives of every State Islamic Religious Councils, one (1) representative from the Ministry of Finance, one (1) representative from the Economic Planning Unit, Prime Minister's Department and three (3) representatives from the corporate sector.

The government's commitment in creating a special entity to coordinate waqf real estate development reflects the importance of waqf real estate development. Waqf real estate development in Malaysia has not been fully explored considering there are still vast swathes of waqf real estate that have not been developed to fulfil existing social needs.

The main objective of this study paper is to investigate the potential presented by waqf real estate in Malaysia for the purpose of housing development; and to evaluate the extent of waqf real estate development for the purpose of housing could be implemented. In achieving this objective, waqf real estate belonging to Penang State Religious Islamic Council have been selected as case studies. This is in view of Muslim housing ownership in Penang being quite low which is further aggravated by high levels of real estate values and demographic factors creating stiff competition in home ownership in Penang.

A study done by Salfarina, A.G., Nor Malina M., and Azrina, H (2011) found that $40 \%$ of urban population comprises disadvantaged people with low affordability to own housing whereby a three-bedroom two bathrooms apartment with a floor area below 92.9 square metres near the city centre costs in excess of RM245,000 [5].

Hence, the issue of the urban poor not owning safe and comfortable residences has become controversial in Malaysia. This is exacerbated by rising costs in addition to debt liabilities; making the creation of truly affordable home ownership a critical challenge.

It is generally accepted that the development of waqf housing real estate may become one of the solutions in overcoming urban housing woes for the low and medium income groups.

\section{Overview Development of Waqf}

Waqf is a latent economic resource of the Muslims that need to be fully exploited which, if correctly managed, will yield economic revenues benefiting all parties.

Malaysia may be categorised as an Islamic State that only recently activated its waqf system in the last 10 years. In the past, waqf real estate developments in Malaysia typically consist of the construction of mosques and cemeteries; but this has gradually evolved in tandem with the country's economic growth. Now, waqf real estate are developed with 'pondok' religious schools and tahfiz schools on waqf branding. On top of that the establishment of the Waqf Foundation has contributed generously towards the development of small shop bazaars on mosque grounds in collaboration between the Waqf Foundation and the State Islamic Councils. Consequently, waqf real estate developments are made more active with the development of Waqf Hotel in Taiping, Perak; Kuala Terengganu, Trengganu; Port Dickson, Negeri Sembilan and in Melaka.

Waqf land development in Malaysia should not only focus on mosque, musolla and cemetery developments; but taking a cue from other countries' waqf real estate developments, Malaysia must break new frontiers in waqf real estate developments. The development of waqf real estate requires financing, thus the creation of cash waqf concept.

Magda (2013) iterated that cash waqf-financed projects need not be confined to only religious natured developments but should also accommodate current needs of the ummah [6].

Numerous studies have been done on the development of various real estate sectors on waqf lands. Magda (2012) further iterated that waqf real estate development is wide ranging; citing 5 countries namely Indonesia, Sudan, Turkey, UK and Kuwait that have paved inroads into waqf real estate development encompassing various sectors. Table 1 shows various waqf real estate that have been developed in the above countries [7]. 
Table 1: List of waqf real estate

\begin{tabular}{|c|c|}
\hline \multicolumn{2}{|c|}{ List of old waqf real estate } \\
\hline 1. Agriculture lands & 16. Stables \\
\hline 2. Universities & $\begin{array}{l}\text { 17. Carpentry } \\
\text { Workshops }\end{array}$ \\
\hline 3. Schools & 18. Clinics \\
\hline 4. Hospitals & 19. Money changers \\
\hline 5. Clinics & 20. Textile Factories \\
\hline 6. Pharmacies & 21. Hotels \\
\hline 7. Bakeries & 22. Silk Factories \\
\hline 8. Butcheries & $\begin{array}{l}\text { 23. Leather-dying } \\
\text { Factories }\end{array}$ \\
\hline 9. Water supplies & 24. Match Factories \\
\hline 10. Restaurants & 25. Soap Factories \\
\hline 11. Tailors & $\begin{array}{l}\text { 26. Aggregate-making } \\
\text { Factories }\end{array}$ \\
\hline 12. Goldsmiths & 27. Olive oil Factories \\
\hline 13.Orphanages & $\begin{array}{l}28 . \\
\text { Crockery and Candle } \\
\text { Factories }\end{array}$ \\
\hline 14. Shoemakers & $\begin{array}{ll}29 . & \text { Boat-making } \\
\text { Factories } & \end{array}$ \\
\hline 15. Highways & $\begin{array}{ll}30 . & \text { Weaponry } \\
\text { Factories } & \end{array}$ \\
\hline
\end{tabular}

Source: Magda (2012)

According to A.Hassan (2010) waqf is an instrument that applies the concept of charity and is non-profit oriented. The public sector can collaborate with the private sector towards uplifting the socio-economic standing of the community[8]. This would strongly justify the development of endowment assets for the purpose of charity according to current needs.

\subsection{The need for housing development on waqf land}

In the context of a developing country such as Malaysia, the local house prices will benefit housing investors looking to make a quick profit optimisation on housing purchases. In contrast, waqf housing developments will be lower in price than conventional housing development of similar type in the local housing market. This strategy is to ensure target groups' affordability is achieved.

The Government of Malaysia (GoM) has realised that housing is a critical need for every member of the population. It is also an important component of the economic parameter. The GoM has formulated policies and programs tailored to ensure every eligible Malaysian has an opportunity to forge a suitable place in the greater scheme of things, as their basic need [9].
Perumahan Rakyat 1Malaysia Act 2012 (Act 739) is one of the government's initiatives to monitor all matters relating to the development and construction of dwelling houses, infrastructure and facilities. PR1MA programs aim at handling the needs for sustainable housing and urban community living in Malaysia.

Affordability issues in Malaysia have never been seriously discussed in detail and no specific studies on housing affordability have been carried out. The term 'affordable housing' being widely used by housing developers in Malaysia is a misnomer and basically becomes their selling point without any credible fact or index as a basis of reference. The same phenomenon exists among housing developers in other Asian countries where formal studies on housing affordability have never been done as compared to developed countries such as the United States, Germany, Spain, United Kingdom, Italy and the Netherlands [10].

Any study on the main role regarding the provision of housing and municipalities is the government's responsibility. Even though there is a variation in such role between developing countries and developed countries, the public sector is still very much needed to provide affordable housing [11].

Therein lies the question as to why must waqf real estate be developed as housing areas? The answer lies in the wide swathes of undeveloped waqf lands that can fulfil immediate housing shortages in Malaysia today. Limited income levels but corresponding high house price levels have isolated medium and low income earners from the housing market. As a result of this social mobility imbalance, it is not impossible that community wellbeing will be affected giving rise to increased incidences of criminal cases.

Why do the target groups desert housing programs provided by the government? A study by Reina Vincent and Begley Jaclene (2014) found that ownership structures, local price increments, and affordability are the three main determinants [12].

It is clear that the housing programs provided did not allow target groups to afford owning 'affordable housing'.

Real estate price increases have for a long time become a thorn in the side for house owners in Malaysia to the extent that owning a house now means a greater corrosion of capital compared to the scenario in the past. A recent study done by Demographia endorsed what has been common knowledge, that Malaysia has a 'very unaffordable' housing market with house prices hovering in the range of 5.5 times the median income as compared to 5.1 times the median income in Singapore [13].

The Malaysian Department of Statistics quoted in their report on Household Income and Basic Amenities Survey 2014 that the median monthly household income for Malaysians in 2014 increased by 11.7 percent per annum to RM4,585 from RM3,626 in 2012 [14].

Due to this ever increasing housing issue and based on the main objective of this paper, it is perceived that 'waqf housing schemes' will be able to fill the void of providing affordable safe and comfortable housing for the target groups in tandem with the objective of waqf as an instrument to solve community economic woes. 


\subsection{Overview of housing affordability in Malaysia}

Table 2 shows house prices in Malaysia indicating housing real estate continuing to monopolise real estate market activities taking average house prices in 2014 at RM295,345 and increasing to RM312,050 in 2015; an increase of 5.7 percent. Kuala Lumpur is the most attractive global city in Malaysia, listed in 2014 and 2015 with increases of RM42,135; which is from RM676,620 to RM718,755 with an increase of 6.7 percent in house prices. House prices in Penang rregistered RM355,374 in 2014 and increased in 2015 in the range of 3.8 percent to RM368,849. All states recorded market activity growths in terms of house prices. The low income earners have such relatively low purchasing power that they could not even afford to buy a house!

Table 2: All House Prices by State in Malaysia

\begin{tabular}{|l|c|c|}
\hline $\begin{array}{c}\text { All House Prices } \\
\text { by State }\end{array}$ & $\begin{array}{c}\text { All House } \\
\text { Prices (RM) } \\
\mathbf{2 0 1 4}\end{array}$ & $\begin{array}{c}\text { All House Prices } \\
\text { (RM) Q3/ 2015 }\end{array}$ \\
\hline Malaysia & 295,345 & 312,050 \\
\hline Kuala Lumpur & 676,620 & 718,755 \\
\hline Selangor & 441,383 & 469,250 \\
\hline Johor & 234,126 & 243,509 \\
\hline Pulau Pinang & 355,374 & 368,849 \\
\hline Negeri Sembilan & 179,537 & 196,750 \\
\hline Perak & 174,021 & 182,721 \\
\hline Melaka & 159,360 & 170,827 \\
\hline Kedah & 159,249 & 164,234 \\
\hline Pahang & 201,282 & 204,108 \\
\hline Terengganu & 209,043 & 217,647 \\
\hline Kelantan & 163,633 & 165,883 \\
\hline Perlis & 144,411 & 156,324 \\
\hline Sabah & 425,166 & 449,022 \\
\hline Sarawak & 361,756 & 389,946 \\
\hline Source: National & Real estate & Information \\
\hline NAPIC) (2015) & & \\
\hline
\end{tabular}

\subsubsection{Owning, purchasing and affordability}

Home ownership rates in Malaysia are quite high averaging 72.5 percent in contrast with developed countries like Singapore at 70 percent within the same year. However, these rates published by the Malaysian Department of Statistics include informal home ownership. A large percentage of housing stock contributing to the 2010 Census was not included in the NAPIC-published estimates that only consider formal housing accounts [15]. This effectively connotes that home ownership rates in Malaysia are below 72 percent as home ownership and home occupancy are two different things. An occupied home may mean it is a rented home.

Housing ownership is best reflected by financial independence and the country's rapid development. It is directed to ensure that housing is provided as a main factor that every group of income earners can afford to own, be they high, medium or even low income earners [16].

The government recognised that housing is a major human need and one of the critical components in urban economics. The My First Home Scheme has enabled young people categorised as poor with monthly household income of less than RM3,000 to own houses priced in the range of RM100,000 to RM220,000. These young buyers will be approved for 100 percent financing for a repayment period of 30 years [17].

The development of social housing finance market remains the best solution for the government to aid the needy to own their own houses. Waqf housing has emerged as a viable alternative that could solve housing woes among the low and medium income groups. This is not a matter of real estate investment or real estate inheritance but the existing scenario of a high number of people living in deplorable conditions due to insufficient income calls for unconventional solutions.

The sign of a fully functional market is when median prices for the entire housing market is 3 times the median gross annual household income [15].

Figure 1 depicts household income distribution in Malaysia in 2014. Of the total, almost 20 percent earn below RM2,000 and only 5 percent own more than RM12,000 per month; reflecting very low home ownership affordability.

Figure 1: Distribution of household income by category, 2014

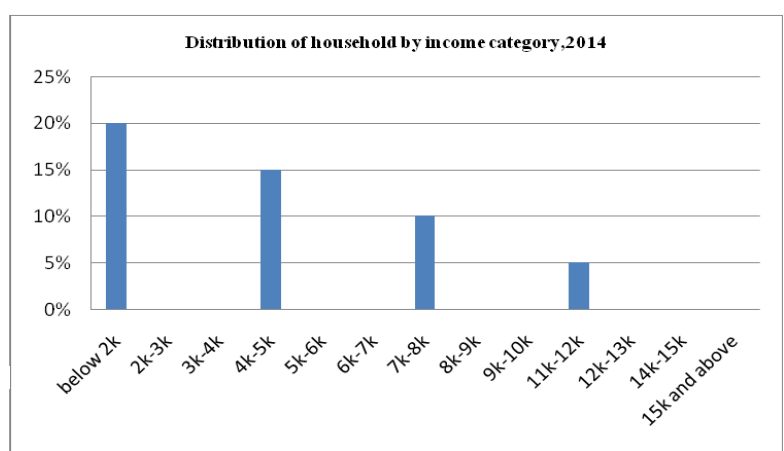

Source: Khazanah Research Institute (2015)

With all due respect, the government has implemented various affordable housing programs whether through joint ventures or through its agencies. Table 3 shows a list of affordable housing projects implemented by the government. 
Table 3: Public affordable housing schemes in Malaysia

\begin{tabular}{|c|c|c|}
\hline $\begin{array}{c}\text { Affordable } \\
\text { scheme }\end{array}$ & $\begin{array}{c}\text { Range of } \\
\text { offered house } \\
\text { price (RM k) }\end{array}$ & $\begin{array}{c}\text { Income range } \\
\text { (RM k per month ) }\end{array}$ \\
\hline $\begin{array}{c}\text { RMM Pulau } \\
\text { Pinang }\end{array}$ & $100-400$ & $0-10$ \\
\hline PR1MA & $150-400$ & $3-10$ \\
\hline RMM SPNB & $50-300$ & $0-10$ \\
\hline RUMAWIP & $50-300$ & $0-10$ \\
\hline PPA1M & $150-300$ & $0-8$ \\
\hline $\begin{array}{c}\text { Rumahku } \\
\text { Selangorku }\end{array}$ & $100-250$ & $0-8$ \\
\hline DPR Johor & $100-200$ & $0-5$ \\
\hline MyHome & $80-180$ & $3-5$ \\
\hline $\begin{array}{c}\text { RMM } \\
\text { Sarawak }\end{array}$ & $80-180$ & $0-3$ \\
\hline
\end{tabular}

Source: Khazanah Research Institute (2015)

Table 3 above clearly reflects the government's commitment to aid affordable housing for the target groups. Sadly it is still insufficient as the target groups vying for such housing far exceed the numbers supplied by the government.

Hence the role played by waqf housing real estate must be optimised to achieve the aim of aiding home ownership among the low and medium income groups in Malaysia.

\section{Research Objectives and Research Design}

This study aims at investigating the inroads made by waqf real estate development specifically for housing in Malaysia. Kahf (1998) proposed that other social welfare activities via waqf must also be developed to become the main backbone for the third sector ie neither public nor private non-profit making sector [18]. This arose from previous studies on waqf which were more inclined towards waqf management and rules with little attention given to other aspects of waqf such as waqf accounting systems and dissemination of waqf reports to users.

In view of the epistemological variables relationship between waqf housing projects and their management, the effecticeness of waqf housing projects has been taken as a data collection strategy. Qualitative analysis of data obtained was utilised. Data includes legal sources such as original decrees, legal texts and intellectual articles explaining the concept of waqf rights utilisation for housing, organisational policy papers and guidelines, documentary records, and results of semistructured face to face interviews with officials. This data is used to study waqf housing project thoughts and application.

Waqf institutions in Malaysia which are currently using waqf housing projects are selected, namely Penang State Religious Islamic Council owing to its success in creating the first Waqf Housing Scheme in Malaysia which is Taman Wakaf Seetee Aisah Seberang Jaya, Pualu Pinang. First, telephone interviews were conducted followed by detailed semi-structured face to face interviews. According to Robert (2008) semi-structured interviews are viewed as suitable for this type of study due to the flexibility exercised during the conversations [19]. The small study sample size is valid considering the respondents' expertise level on the subject matter as postulated by Sarah and Rosalind (2012). Interview and conversation sessions were recorded on tape recorders and field notes [20].

In reference to P.Mayring (2000), all recorded data is transferred into text. Transcripters often face difficulty in making out words uttered in text form due to word structures, use of citations, omissions, and misconstrued words or phrases by others [21]. Humans tend to converse at high speed intonations hence transcripters need to exercise care in transcripting conversations into text. Insertion of spacing or comma could change the overall meaning of a sentence. Therefore, every transcript need to be done carefully to reduce mistakes as much as possible (Nigel Mathers et. al, 2002) [22]

Thus the following five data analysis phases proposed by Yin (2011) are perceived as crucial. All data recorded electronically or otherwise is scrutinised and reread. Tape recorders were replayed and rearranged to enable critical information to be reassessed for the study findings. Rearrangement of data is required to ensure analysis of data objectives. Besides that interpretation is also used to understand information providers' validity, and to investigate any implied assumptions, suitable and construed as the respondent's rational views relating to the subject experiences [23].

Three steps are used to assess the effectiveness of the waqf housing project strategy: specific objectives determined by the waqf housing projects; organisational objectives; and target groups' needs. In this study however, the researcher measures effectiveness of waqf housing projects based on the successful construction of waqf housing projects within the advertised period, and how many members of the target groups benefits from the projects.

Since waqf housing projects are still novelty in Malaysia, the author has targeted waqf institutions that possess awareness and vissititude to experiment on this new product, as the measure of waqf housing project success. Penang SIRC for instance, had to overcome multitude of challenges to ensure the success of its pioneer project Taman Waqaf Setee Aisah; specifically in terms of sourcing out financing and finding a developer willing to develop a waqf housing project. The ability of Penang SIRC to attract various parties to participate in their waqf housing project can be used as benchmark besides the number of projects that has been implemented.

The author used the number of projects that has been successfully completed considering waqf housing project is a new product in the realm of waqf development in Malaysia, and not based on the investment value of the project. Paradoxically, this could lead to some presumptive statements. 


\section{Fund raising for waqf housing projects}

Waqf institutions are now collecting funds through three means, including grants from the goverment, self financing, and loans from financial institutions. The first type of financial source is Federal Government Aminah and Tahir Grant (2015) [24].

H.Ahmed (2007) is of the opinion that financial institution can create funds and investments in the form of activities yielding future returns. In doing so, the financial institution faces challenges relating to problems and risks inherent in finnancing. Prior to financing decisions, the financier needs to identify the right projects to ensure returns on investment [25].

According to the Shariah Panel of Maybank Berhad Group, the cash waqf is allowed provided the waqf money is managed in such a way as to maintain its permanence characteristic. This can be done by investing the money in construction projects or using cash waqf in the purchase of any permanent or usable asset [26].

Waqf institutions need to augment their financial funding so that high impact projects can be realised. Funding is defined as financial grants by waqf institutions from their own coffers towards the development and management of waqf real estate, devoid of funding by other financial bodies.

\subsection{Concept of al-ijarah on housing schemes on waqf lands in Malaysia}

Al-ijarah refers to an agreement whereby a Waqf Institution (SIRC) leases a waqf land to another party at a rate agreed to by both parties [27]. By adhering to alijarah concept, the waqf institution indirectly generates income from the lease payments for lease terms 30,60 or 99 years as set out under the National Land Code.

Al-ijarah as adopted in long term lease agreement (alHijr) infers that the developer has exclusive rights on the real estate for a long period by selling the rights to the long lease for a hefty one-time payment. The developer may then waqf lands using his own resources and at his own risk. At the expiry of the lease term, the waqf land will be surrendered to the waqf institution after the developer has enjoyed exclusive rights to develop and use said land model [27].

Upon completion of the building construction, the waqf institution will receive the building leasehold value for a specific term set out in the agreement. The owners or buyers of the completed housing units will receive the al-ijarah concept similar to the conventional leasehold land concept enshrined in the National Land Code (1965).

Buildings built on expired leasehold lands (usually 99 years lease for housing), will have to be renewed at certain values. These will become revenue to the waqf institution. These lands are not exempted from premium payment, the same as that charged on leasehold renewal lands under State Leases.
Waqf real estate ownership is not an issue as buyers only receive the benefit or right to use, not the right to own. Figure 2 explains the al-ijarah process:

Figure 2: Preliminary Framework of Al-Ijarah Concept

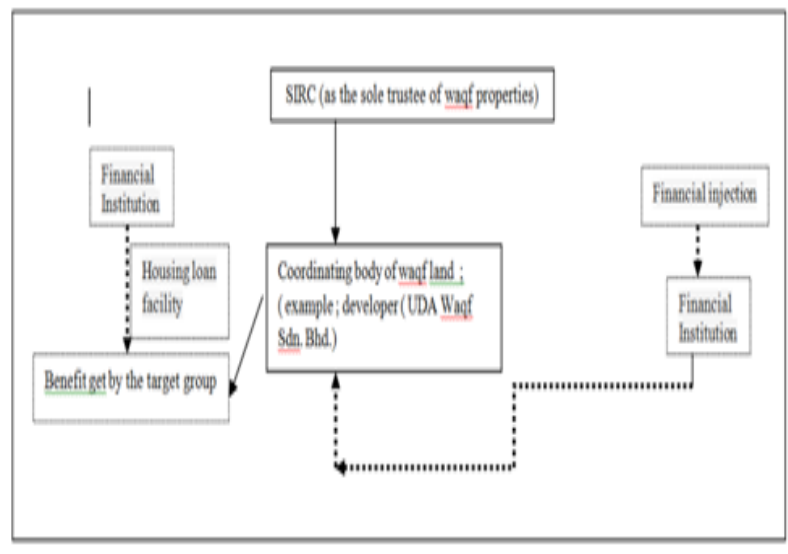

Source: Researcher (2016)

\section{Implementation of housing schemes}

The success of the Setee Aisah waqf housing scheme in 2003 has made Penang SIRC a competitive waqf institution in developing the local ummah economy. The success of Penang SIRC in forging collaboration with UDA Land Sdn. Bhd as well as with Al-Rajhi Bank and Bank Islam Malaysia Berhad has received deep appreciation among waqf activists. With the successful completion of the waqf project, UDA has made further inroads by establishing UDA Waqf Sdn. Bhd. which will also focus on waqf housing developments in other states. Financial institutions have also opened their eyes on the feasibility of waqf products on their cashflows. It is evident that waqf real estate developments are not third class status confined merely to mosques and cemeteries. In fact waqf real estate development may be made more comprehensive in line with the community needs.

\subsection{Analysis on Interview Sessions with Waqf Officials}

Analysis results of semi-structured interviews conducted by the author with 2 waqf officials of the Penang SIRC may be categorised by referring to Table 4 below. The author was not able to meet with the Waqf Chief Executive Officer who was then overseas on waqf business. The author interviewed these officials separately.

The questionnaire instrument used by the author was based on the author's prior field study on Terengganu SIRC [28]. Both respondents gave their full cooperation. The respondents did not have Islamic Studies background prior to starting his career with Penang SIRC. Nevertheless they have high motivation working in the waqf section. During the interviews, respondents 1 and 2 displayed important documents pertaining to waqf housing project for the author's analysis. 
Respondents 1 and 2 were of permanent position status; but 6 other staffs were contract staffs. This would free them to find other more stable job opportunities. Respondent 1 has a high academic background at master's level even though his position at SIRC does not commensurate with his academic qualifications. Thus it is possible that Respondent 1 may leave his waqf position to look for a better higher paying job.

Respondent 1 dan 2 were of the opinion that valuation of waqf real estate done by the Valuation and Real estate Services Department, Ministry of Finance should not be charged fees as waqf real estate is charitable in nature.

As a result of interviews with both Respondent 1 and 2 who gave full cooperation, the author was able to review all documents pertaining to waqf housing schemes. They also helped the author identify 9 waqf housing projects which have been completed, in the process of construction, and will be developed.

Table 4: Analysis of Interviews with SIRC Waqf Officials

\begin{tabular}{|c|c|c|}
\hline $\begin{array}{c}\text { Questioning } \\
\text { Theme }\end{array}$ & $\begin{array}{c}\text { Respondent } \\
1\end{array}$ & $\begin{array}{c}\text { Respondent } \\
2\end{array}$ \\
\hline $\begin{array}{l}\text { 1) Work } \\
\text { Experience }\end{array}$ & $\begin{array}{l}\text { Health Department } \\
\text { (Grade 41) }\end{array}$ & Fresh graduate \\
\hline $\begin{array}{l}\text { 2) Position in } \\
\text { Waqf Institution }\end{array}$ & $\begin{array}{l}\text { Assistant } \\
\text { Administrative } \\
\text { Officer }\end{array}$ & $\begin{array}{l}\text { Assistant } \\
\text { Administrative } \\
\text { Officer }\end{array}$ \\
\hline 3) Status & Permanent & Permanent \\
\hline $\begin{array}{l}\text { 4) Education } \\
\text { Background } \\
\end{array}$ & $\begin{array}{l}\text { Master in Business } \\
\text { Management }\end{array}$ & STPM \\
\hline 5) Experience & 1 year & 4 years \\
\hline 6) Field of Work & $\begin{array}{l}\text { Planning on waqf } \\
\text { land }\end{array}$ & $\begin{array}{l}\text { Real estate } \\
\text { management on } \\
\text { Waqf assets }\end{array}$ \\
\hline $\begin{array}{l}\text { 7) Opinion on } \\
\text { waqf housing }\end{array}$ & $\begin{array}{l}\text { Good performance, } \\
\text { many projects }\end{array}$ & $\begin{array}{l}\text { Good performance, } \\
\text { many projects }\end{array}$ \\
\hline $\begin{array}{l}\text { 8) How many } \\
\text { staffs in Waqf } \\
\text { Department? }\end{array}$ & 9 staff, inadequate & 9 staff, inadequate \\
\hline 9) Issues? & Abandoned surau & $\begin{array}{l}\text { Waqf Real Estate } \\
\text { Arrears involving } \\
\text { RM200K }\end{array}$ \\
\hline $\begin{array}{l}\text { 10) Challenges } \\
\text { in handling waqf } \\
\text { land? }\end{array}$ & $\begin{array}{l}\text { Declarations of } \\
\text { endowment } \\
\text { deceased is } \\
\text { unacceptable for } \\
\text { proving endowment }\end{array}$ & Unpaid rents \\
\hline 11) Court Case & $\begin{array}{l}\text { The heirs do not } \\
\text { want to leave the } \\
\text { waqf land. There } \\
\text { are } 13 \text { of them. }\end{array}$ & $\begin{array}{l}\text { We always win } \\
\text { court cases } \\
\text { although the heirs } \\
\text { claimed it. }\end{array}$ \\
\hline $\begin{array}{l}\text { 12) Does } \\
\text { valuation being } \\
\text { carried out? }\end{array}$ & $\begin{array}{l}\text { No, the fee is too } \\
\text { expensive. }\end{array}$ & $\begin{array}{l}\text { Yes, to identify the } \\
\text { rent }\end{array}$ \\
\hline $\begin{array}{l}\text { 13) Developed } \\
\text { waqf project }\end{array}$ & Excessive & Considerable \\
\hline $\begin{array}{l}\text { 14) Reason of } \\
\text { delayed project }\end{array}$ & Financial problem & Financial problem \\
\hline
\end{tabular}

\subsection{List of projects under Penang SIRC}

Table 5 shows completed housing scheme projects as well as discussion-level projects implemented by Penang SIRC. These housing project activities are included under the 9 projects identified earlier. A project located in Teluk Ayer Tawar is under construction and expected to be fully completed in 2018 offering 8 storey and 12 storey apartment blocks comprising 152 apartment parcels.

Table 5: List of projects under Penang SIRC

\begin{tabular}{|c|c|}
\hline \multicolumn{2}{|c|}{$\begin{array}{c}\text { Projects under Penang SIRC For Housing / Residential } \\
\text { Units }\end{array}$} \\
\hline 1) Project & $\begin{array}{c}\text { Taman Wakaf Seetee Aisah } \\
\text { Seberang Jaya }\end{array}$ \\
\hline Total unit & $\begin{array}{c}76 \text { units double storey terrace } \\
\text { houses }\end{array}$ \\
\hline Year to be completed & 2013 \\
\hline $\begin{array}{l}\text { Total Cost of Project } \\
\text { ( RM) }\end{array}$ & 21 million \\
\hline Project status & Completed \\
\hline Types of Agreement & $\begin{array}{c}\text { ( Ijarah ) } \\
\text { A1 Rajhi Bank \& Bank } \\
\text { Islam Malaysia }\end{array}$ \\
\hline $\begin{array}{l}\text { Land area } \\
\text { ( acre) }\end{array}$ & 9.86 \\
\hline 2) Project & $\begin{array}{l}\text { Medium Cost Apartments, } \\
\text { Abdul Cauder, Jalan } \\
\text { Mengkuang, Seberang Prai } \\
\text { Utara }\end{array}$ \\
\hline Total unit & ( upon discussion) \\
\hline Year to be completed & ( upon discussion) \\
\hline $\begin{array}{l}\text { Total Cost of Project } \\
\text { ( RM) }\end{array}$ & $\begin{array}{l}\text { Targeted Cost } \\
20 \text { million }\end{array}$ \\
\hline Project status & Proposal \\
\hline Types of Agreement & Ijarah \\
\hline $\begin{array}{l}\text { Land area } \\
\text { ( acre) }\end{array}$ & 2.625 \\
\hline 3) Project & $\begin{array}{l}\text { Medium Cost Apartments, } \\
\text { Wakaf Siti Bt. Abdul Rahman } \\
\text { on lots } 1093 \text { \& 1094, Sungai } \\
\text { Nibong, Mukim 12, DBD, } \\
\text { Pulau Pinang }\end{array}$ \\
\hline Total unit & 77 parcels (14 storeys) \\
\hline Year to be completed & Targeted in 2016 \\
\hline $\begin{array}{l}\text { Total Cost of Project } \\
\text { ( RM) }\end{array}$ & $\begin{array}{l}9 \text { million (land value) } \\
\text { Construction cost } \\
\text { (upon discussion) }\end{array}$ \\
\hline Project status & $\begin{array}{l}\text { (upon discussion) } \\
\text { Planning }\end{array}$ \\
\hline Types of Agreement & Ijarah \\
\hline $\begin{array}{l}\text { Land area } \\
\text { ( acre) }\end{array}$ & 1.571 \\
\hline
\end{tabular}




\begin{tabular}{|c|c|}
\hline \multicolumn{2}{|c|}{$\begin{array}{c}\text { Projects under Penang SIRC For Housing / } \\
\text { Residential Units }\end{array}$} \\
\hline 3) Project & $\begin{array}{l}\text { Medium Cost Apartments, Lot } \\
\text { 263, Batu Maung, Mukim 12, } \\
\text { Barat Daya, Pulau Pinang }\end{array}$ \\
\hline Total unit & $\begin{array}{l}150 \text { parcels } \\
(15 \text { storeys })\end{array}$ \\
\hline Year to be completed & 2018 \\
\hline $\begin{array}{l}\text { Total Cost of Project } \\
\text { ( RM) }\end{array}$ & 50 million \\
\hline Project status & Under Construction \\
\hline Types of Agreement & Ijarah \\
\hline $\begin{array}{l}\text { Land area } \\
\text { ( acre) }\end{array}$ & 5.5 \\
\hline 4) Project & $\begin{array}{l}\text { Medium Cost Apartments, } \\
\text { Wakaf Muhammad Hashim } \\
\text { bin Haji Abdullah, Lot 192, } \\
\text { Seberang Jaya, Mukim 1, SPT }\end{array}$ \\
\hline Total unit & 68 parcels (11 storeys ) \\
\hline Year to be completed & (upon discussion) \\
\hline $\begin{array}{l}\text { Total Cost of Project } \\
\text { ( RM) }\end{array}$ & (upon discussion) \\
\hline Project status & proposal \\
\hline Types of Agreement & Ijarah \\
\hline $\begin{array}{l}\text { Land area } \\
\text { ( acre) }\end{array}$ & 1.142 \\
\hline 5) Project & $\begin{array}{l}\text { Medium Cost Apartments, } 15 \\
\text { Storeys, Half of the lot, Lot } \\
\text { PT 146, Balik Pulau, Mukim G, } \\
\text { Daerah Barat Daya, Pulau } \\
\text { Pinang. }\end{array}$ \\
\hline Total unit & 200 parcels \\
\hline Year to be completed & 2018 \\
\hline $\begin{array}{l}\text { Total Cost of Project } \\
\text { ( RM) }\end{array}$ & 50 million \\
\hline Project status & Under Construction \\
\hline Types of Agreement & Ijarah \\
\hline $\begin{array}{l}\text { Land area } \\
\text { ( acre) }\end{array}$ & ( \\
\hline 6) Project & $\begin{array}{l}\text { Medium Cost Apartments and } \\
\text { low cost flats, Taman Wakaf } \\
\text { Seetee Aisah (Fasa 2), Wakaf } \\
\text { Seetee Aisah, Lots 200, } 252 \text { \& } \\
\text { 3117, Seberang Jaya, } \\
\text { Mukim 4, SPT }\end{array}$ \\
\hline Total unit & ( upon discussion) \\
\hline Year to be completed & ( upon discussion) \\
\hline $\begin{array}{l}\text { Total Cost of Project } \\
\text { ( RM) }\end{array}$ & ( upon discussion) \\
\hline Project status & Proposal \\
\hline Types of Agreement & Ijarah \\
\hline $\begin{array}{l}\text { Land area } \\
\text { ( acre) }\end{array}$ & 7.322 \\
\hline
\end{tabular}

\begin{tabular}{|c|c|}
\hline 7) Project & $\begin{array}{l}\text { Medium Cost Apartments, } \\
\text { Wakaf Shekh Eusoff, on Lots } \\
1396 \text { \& Lot 1606, Jalan Air } \\
\text { Itam, Sek. 5, DTL Pulau } \\
\text { Pinang }\end{array}$ \\
\hline Total unit & (upon discussion) \\
\hline $\begin{array}{l}\text { Year to be } \\
\text { completed }\end{array}$ & (upon discussion) \\
\hline $\begin{array}{l}\text { Total Cost of } \\
\text { Project } \\
\text { ( RM) } \\
\end{array}$ & (upon discussion) \\
\hline Project status & proposal \\
\hline $\begin{array}{l}\text { Types of } \\
\text { Agreement }\end{array}$ & Ijarah \\
\hline $\begin{array}{l}\text { Land area } \\
\text { (acre) }\end{array}$ & 14.97 \\
\hline 8) Project & $\begin{array}{c}\text { Medium Cost Apartments, } \\
\text { Lots } 6247 \text { \& 6249, Teluk Air } \\
\text { Tawar, Mukim 7, SPU, Pulau } \\
\text { Pinang }\end{array}$ \\
\hline Total unit & $\begin{array}{l}152 \text { parcels } \\
(8 \text { storeys and } 12 \text { storeys }) 2 \\
\text { blocks }\end{array}$ \\
\hline $\begin{array}{l}\text { Year to be } \\
\text { completed }\end{array}$ & 2018 \\
\hline $\begin{array}{l}\text { Total Cost of } \\
\text { Project } \\
\text { ( RM) } \\
\end{array}$ & 50 million \\
\hline Project status & Under Construction \\
\hline $\begin{array}{l}\text { Types of } \\
\text { Agreement }\end{array}$ & Ijarah \\
\hline $\begin{array}{l}\text { Land area } \\
\text { (acre) }\end{array}$ & 5.525 \\
\hline
\end{tabular}

\subsection{Waqf Housing Aimed at Affordablity}

Affordable housing in Penang, especially on the island is very limited. However once waqf housing development commences, low and medium income groups may have their shot at home ownership on a prestigious real estate on Penang Island.

Initially, some financial institutions were unwilling to take risks becoming involved in waqf real estate developments. This is because they were unclear on the 'ingredients' of waqf. The synergy between banks and waqf developments in the Arab states is very close. Hence, Al Rajhi Bank grabbed the opportunity to finance Taman Wakaf Seetee Aisah Seberang Jaya when they received the offer to help. Due to rapid urbanisation of the Georgetown City Centre, all proposed housing developments are only approved as multi storey housing developments such as apartments. Although the first waqf housing scheme in Penang was developed as double storey houses, the focus now is more on medium cost apartments to ensure they benefit greater number of target group members. 


\section{Discussions and conclusion}

Waqf is the problem-solver to balance community development but Malaysia is a multi-racial country and the concentrations of any one ethnic group are not in accordance with the 1Malaysia Agenda. Eventually, the movement towards waqf development could solve the imbalance in urban housing developments. The main thrust of the Malaysian National Housing Policy is to provide accessible, adequate, affordable quality housing for all Malaysians especially the low income groups. In 1982, the government enforced the 30 percent quota of low cost housing on private developers as social service responsibility to complement the Government's commitment to provide affordable housing. Housing projects on lands exceeding 5 acres must allocate at least 30 percent of their housing units as low cost housing (Datuk Eddy Chen Lok Loi - REHDA Malaysia)

The concept of waqf housing development with a new and innovative framework, specifically in the use of affordable materials and construction techniques, was given emphasis. Indirectly, aspects of life quality enhancement and maintaining sustainability of waqf real estate are created. Thus, the agenda to create comfortable and affordable housing will be acheieved.

The involvement of market-established developers in waqf projects is perceived as beneficial in enhancing their corporate image in terms of Social Corporate Responsibility (CSR). Waqf housing projects could greatly aid in eradicating low purchasing power among the needy groups so that it will automatically improve community social mobility.

Taman Wakaf Seetee Aisah Seberang Jaya Pulau Pinang is not the first housing project for UDA Holdings Berhad. UDA's Land Department has developed a sizable number of real estate in cities around the country earmarked to fulfil the national housing needs across income spectrums. Some of these are Bandar Tun Hussein Onn, Cheras, Selangor; Bandar UDA Utama, Pulai, Johor; Bandar Pauh Jaya, Permatang Pauh, Pulau Pinang; Tanjung Tokong, Pulau Pinang; Bandar Baru UDA, Johor Bahru, Johor; Pusat Bandar Tampoi, Johor Bahru, Johor; and Skudai Kanan, Johor Bahru, Johor.

The involvement of financial institutions and developers in waqf projects has convinced them to utilise waqf lands efficiently. The good performance on waqf projects is very much dependent on the full commitment at the best level from every party involved in waqf development, specifically the government, the public throughout the period.

\section{Acknowledgement: Funding Sources}

This research was supported by Universiti Teknologi MARA and received funding from the Department of Higher Education, Ministry of Higher Education (MOHE) which is under the Dana Pembudayaan Penyelidikan (RAGS) GRANT (RAGS/2013/UiTM/SSI11/

\section{References}

[1] Kais Dukes, "Sunan an-Nasa'i 3691," Book 32, Hadith 4. [Online]. Available:

http://sunnah.com/nasai/32/4. [Accessed: 05-Feb2016].

[2] M. Dr. Uswatun Hasanah, "Inovasi Pengembangan Wakaf di Berbagai Negara," Artikel, 2008. [Online]. Available: http://bwi.or.id/index.php/in/publikasi/artikel/222 -inovasi-pengembangan-wakaf-di-berbagainegara. [Accessed: 04-Feb-2016].

[3] B. Yediyyildiz, "Place of the Waqf in Turkish Cultural System," 1996, 1996. [Online]. Available:

http://yunus.hacettepe.edu.tr/ yyildiz/placeofthe waqf.htm. [Accessed: 04-Feb-2016].

[4] Quran.com, “QURAN.COM. ALL RIGHTS RESERVED 2015,” 2015. [Online]. Available: http://quran.com/2. [Accessed: 05-Feb-2016].

[5] S. A. Gapor, N. M. Malik, and A. Husin, "Trends , Problems and Needs of Urban Housing in Malaysia," Int. J. Soc. Educ. Econ. Manag. Eng., vol. 5, no. 2, pp. 37-41, 2011.

[6] M. I. A. Mohsin, "Financing through cash-waqf: a revitalization to finance different needs," Int. J. Islam. Middle East. Financ. Manag., vol. 6, no. 4, pp. 304-321, 2013.

[7] M. I. A.Mohsin, "Waqf-shares : new product to finance old waqf real estate," Bank Bank Syst., vol. 7, no. 2, pp. 72-78, 2012.

[8] A. Hassan, "MANAGEMENT AND DEVELOPMENT OF THE MANAGEMENT AND DEVELOPMENT OF THE," in Seventh International Conference - The Tawhidi Epistemology: Zakat and Waqf Economy, Bangi 2010, 2010, pp. 309-328.

[9] T. S. Ong, "Factors Affecting the Price of Housing in Malaysia," J. Emerg. Issues Econ. Financ. Bank., vol. 1, no. 5, pp. 414-429, 2013.

[10] Z. Hashim, "House price and affordability in housing in Malaysia," Akademika, vol. 78, pp. 37-46, 2010.

[11] D. Özdemir, "The Role of the Public Sector in the Provision of Housing Supply in Turkey, 19502009," Int. J. Urban Reg. Res., vol. 35, no. November 2011, pp. 1099-1117, 2011.

[12] V. Reina and J. Begley, "Reprint of "will they stay or will they go: Predicting subsidized housing opt-outs,", J. Hous. Econ., vol. 24, pp. 122-137, 2014.

[13] www.iMoney.my, "Malaysia Budget 2016 : Can You Afford A House Now?," 24/10/2015. [Online]. Available:

http://english.astroawani.com/malaysianews/budget-2016-can-you-afford-house-now77733. [Accessed: 06-Feb-2016].

[14] M. Department of Statistics, "Average Monthly Income of Malaysian Households At," 2014. 
[15] Dr-Suraya-Ismai, "Making Housing Affordable," 2015.

[16] M. S. Suhaida, N. M. Tawil, N. Hamzah, a I. Che Ani, and M. M. Tahir, "A Conceptual Overview of Housing Affordability in Selangor, Malaysia," Int. J. Soc. Hum. Sci. Eng., vol. 4, no. 12, pp. 287-289, 2010.

[17] M. S. Suhaida, N. M. Tawil, N. Hamzah, A. I. Che-Ani, H. Basri, and M. Y. Yuzainee, "Housing Affordability: A Conceptual Overview for House Price Index," Procedia Eng., vol. 20, pp. 346-353, 2011.

[18] M. Kahf, "FINANCING THE DEVELOPMENT of AWQAF REAL ESTATE," IRTI, Kuala Lumpur, Malaysia, 1998.

[19] Robert Wood Johnson Foundation, "Developing the interview guide," Citation: Cohen D,

Crabtree B. "Qualitative Research Guidelines Project." July 2006.

http://www.qualres.org/HomeInte-3595.html, 2008. [Online]. Available:

http://www.qualres.org/HomeInte-3595.html. [Accessed: 06-Feb-2016].

[20] S. E. Baker, R. Edwards, P. Adler, H. S. Becker, and A. Doucet, "How many qualitative interviews is enough ?," national Centre for Research Method, 20121. [Online]. Available: eprints.ncrm.ac.uk/2273/4/how_many_interviews .pdf. [Accessed: 06-Feb-2016].

[21] P. Mayring, "Qualitative Content Analysis," 2000, vol. 1, no. 2, 2000.

[22] N. Fox and A. HunnHunn, Amanda, "Trent Focus for Research and Development in Primary Health Care Using," 2002.

[23] ROBERT K. YIN, QUALITATIVE RESEARCH FROM START TO FINISH, 98765 ., vol. 53, no. 9. New York, 2011.

[24] A. B. Mohsin, M. Tahir, and S. Hj, "THE EFFECTIVENESS OF SAHAM WAQF ON ADEQUACY 2 FUNDS FOR," Int. J. Real Estate Stud., vol. 9, no. 2015, p. 33, 2015.

[25] H. Ahmed, "Waqf -Based Microfinance: Realizing The Social Role of Islamic Finance 'Integrating Awqaf in the Islamic Financial Sector," in Integrating Awqaf in the Islamic Financial Sector, 2007, pp. 1-22.

[26] M. Ramadhan, F. Ellias, A. F. Kadir, and M. N. Haron, "Parameter syariah untuk wakaf tunai."

[27] M. N. A. Zulkifli Hasan, "The Investment Of Waqf Land As An Instrument Of Muslims' Economic Development In Malaysia," in Dubai International Conference on Endowments' Investment, 4-6th February 2008, 2008, pp. 1-25.

[28] S. Nadiah, M. Ali, A. Halim, M. Noor, N. Nazihah, N. Rashidah, P. Ismail, F. Dahlan, M. Saifol, and A. Shari, "Integrating Awqaf and Zakat: A Case Study of Land Development For The Poor in State Islamic Religious Councils Terengganu, Malaysia," in International Halal Conference 2014 - INHAC 2014, 2014. 